\title{
COVENANTS RUNNING WITH LAND IN NEW JERSEY
}

\section{Albert S. Bolles}

If there has been a somewhat meagre development of legal principles that apply to covenants running with land in $\mathrm{New}$ Jersey, no one will question the fullness of the equitable principles that have been'wrought and applied to them by the courts of equity.

It has been said that the office and operation of the usual covenants for title are personal, binding the representatives of the covenantor, and that they are not real covenants in the sense of the ancient feudal law. This is especially true of three of them: that the grantor is lawfully seised of the premises; that he has a good right to convey them; and that they are free from encumbrances. They do not run with the land nor pass the title to the assignee. They are in language de presenti, and, if not true, are broken as soon as they are made. The two remaining covenants-that the grantee shall enjoy the premises, and that the grantor will warrant and defend the title-are prospective, and are therefore real covenants which run with the land conveyed, and descend to heirs and assignees. ${ }^{1}$ A warranty attaches only to the estate granted, or purported to be granted. Thus a warranty attached to a life estate cannot enlarge the estate which was granted, even though it warrant the land to the life tenant and his heirs general. ${ }^{2}$

This division of covenants prevails in most of the states. The covenants of warranty and quiet enjoyment, which are sometimes regarded as a single covenant, in all jurisdictions are held to run with the land. On the other hand, only in a few states does the covenant of seisin run with the land. ${ }^{3}$ There is, how-

${ }^{2}$ Carter v. Denman, 23 N. J. L. 260 (I852) ; Chapman v. Holmes, Io N. J. L. 20 (1828); see Lot v. Thomas, 2 N. J. L. 297,299 (1805); Garrison v. Sandford, I2 N. J. L. 26I, 264 (I83I).

${ }^{2}$ Adams v. Ross, 30 N. J. L. 505 (1860).

${ }^{3}$ Schofield v. Iowa Homestead Co., 32 Iowa 317 (1871) ; Martin v. Baker, 5 Blackf. 232 (Ind. 1839); Coleman v. Lyman, 42 Ind. 289 (I873); Backus v. McCoy, 3 Ohio 21 I (1827); Great Western Stock Co. v. Saas, 24 Ohio St. 542 (1874). 
ever, a wide conflict with respect to what constitutes a breach of the covenant of seisin. ${ }^{4}$ There is a growing tendency to regard the covenant against encumbrances as running with the land. ${ }^{5}$ In New York, after many varying decisions, the Court of Appeals has declared that: "The covenant against encumbrances attaches to and runs with the land and passes to a remote grantee through the line of conveyances, whether there is a nominal breach or not when the deed is delivered." ${ }^{6}$ In this tendency the American courts are conforming to the English rule. ${ }^{7}$

This rule has been applied to deeds of lots which abutted on a road ending in a cul-de-sac and described "as laid out across the whole tract," and containing a covenant by which the grantors bound themselves and their heirs and assigns not to erect on the remaining property owned by them, adjoining the property conveyed, any house costing less than a specified amount or nearer than forty feet to the street line. This covenant was held to be personal to the grantees, and did not extend to the benefit of subsequent purchasers of other lots. ${ }^{8}$ To this illustration may be added another of a personal covenant, in which damages were not to be claimed for the future use of land by a railroad. In a deed from $A$ to $C$ the latter covenanted for himself, his heirs and assigns, that neither he nor they would claim any damages for injury to the land conveyed from the construction of a railroad that was to be built on $A$ 's adjoining land. The court held that the railroad company could not avail itself of the covenant in that deed because it was not a grant of an easement, nor of a right in the nature of an easement, in the premises conveyed, and

- Mitchell v. Hazen, 4 Conn. 495 (1823); Brady v. Spurck, 27 I11. 478 (I86I) ; Wilson v. Widenham, 5I Me. 566 (I863) ; Marston v. Hobbs, 2 Mass. 433 (1807) ; Stewart v. Drake, 9 N. J. L. I39 (I827) ; Backus v. McCoy, supra note 3 .

${ }^{5}$ Richard v. Brent, 59 I11. 38 (I871) ; Worley v. Hineman, 6 Ind. App. 240, 33 N. E. 260 (1892) ; Beasley v. Phillips, 20 Ind. App. I82, 50 N. E. 488 (I897); Knadler v. Sharp, 36 Iowa 232 (I873); Allen v. Little, 36 Me. I7o (1853); Security Bank v. Holmes, 68 Minn. 538, 7I N. W. 699 (I897); Stiles v. Hobbs, 2 Disn. $57 \mathrm{I}$ (Ohio I856); Cole v. Kimball, 52 Vt. 639 (1880); see Foote v. Burnet, io Ohio 317, 332 (1840).

- Geiszler v. DeGraaf, 166 N. Y. 339, 344, 59 N. E. 993,995 (I901).

744 \& 45 VICT., c. $4 \mathrm{I}, \$ 7$ ( I88I) ; Kingdon v. Nottle, 4 Maule \& S. 53 (1815); Spoor v. Green, L. R. 9 Ex. 99 (1874).

Stevens v. Headley, 69 N. J. Eq. 533, 62 Atl. 887 (1905). 
that the burden of such a covenant, if regarded as a covenant, would not in law run with the land nor bind the alienee in any case except that of landlord and tenant. The covenant in the deed was construed as one inter partes, with $A$ individually, for his personal indemnity. ${ }^{9}$ In another case a tunnel company covenanted with a railroad company that it would not institute condemnation proceedings under any specified land belonging to the railroad company. The covenant was held not to run with the land, and therefore it was not binding on the successor of the tunnel company. ${ }^{10}$ A covenant by a mortgagor to insure the mortgaged land for the benefit of the mortgagee is a personal covenant not running with the land. ${ }^{11}$

A covenant for the maintenance of a railroad crossing will run with the land and will enure to the benefit of the heirs of the grantor. Once located, the crossing cannot be changed save by mutual consent; nor will the court give something as a substitute unless the railroad can show that, under the special conditions of the case, the enforcement of the legal right would be inequitable. ${ }^{12}$ Compensation, however, in a proper case may be awarded for not executing a covenant. ${ }^{13}$ Cases concerning party walls, which involve problems of covenants running with land, have been the sources of much litigation in New York, Illinois, Massachusetts and Pennsylvania, and, to a lesser degree, in other states. The few cases which have reached the higher courts in New Jersey have involved mainly questions of statutory construction. In Hunt $v$. Ambruster ${ }^{14}$ the rule was announced that the right to compensation passes with the ownership of the building. This rule was established by an ordinance of the city of Camden,

${ }^{9}$ Costigan v. Penna. R. R., 54 N. J. L. 233, 23 Atl. 810 (1892).

${ }^{10}$ Morris \& Essex R. R. v. Hoboken \& M. R. R., 68 N. J. Eq. 328, 59 Atl. 332 (1904).

${ }^{11}$ Kaplan v Wilderman, 95 N. J. Eq. 463, 123 Atl. I65 (I924).

${ }^{12}$ Moorhead v. Little Miami R. R., I7 Ohio 340 (1848) ; Speer v. Erie R. R., 64 N. J. Eq. 60I, 54 Atl. 539 (1903); Blakemore v. Glamorganshire Canal Co., I Mylne \& K. 154 (Eng. I832) ; see Morris \& Essex R. R. v. Central R. R. of N. J., 3I N. J. L. 205, 209 (1865).

${ }^{23}$ Sperb v. Metropolitan Elevated Ry., I37 N. Y. 155, 32 N. E. 1050 (1893); New York City v. Pine, I85 U. S. 93, 22 Sup. Ct. 592 (I902); see note (I893) 20 L. R. A. 752.

${ }^{14}$ I7 N. J. Eq. 208 (1865). 
which coincided not only with the general rule, but also with the statutes of many states.

Whether a covenant is of a proper nature to run with the land is a pure question of law, to be decided by the court. The question is not one of the intention of the covenanting parties, regardless of their lawful inclination. Accordingly, ever since Jord Brougham's day, the courts have reiterated his well known declaration that covenantors are not free to invent any covenants that their imagination or caprice may contrive ${ }^{15}$ - a rule approved by the courts in this state. Thus in Brewer $v$. Marshall ${ }^{16}$ a covenant by a grantor of land, that neither he nor his assigns would sell any marl from the premises adjoining the land sold, could not be enforced against an alienee whom the grantor sought to burden with the covenant. Said Chief Justice Beasley:

". . . the covenant in question appears to be destitute of all the essentials of a legal agreement . . I cannot say that the covenant is legal, anymore than I can say that a covenant on the part of a farmer not to sell, nor permit any of the future owners of his farm to sell, any grain to be grown on his farm, would be legal." 17

Another question, in the process of settlement in other jurisdictions, has long been settled in New Jersey. A deed poll, accepted by the proper parties, is regarded as a covenant, as much so as if signed and sealed by both of them. ${ }^{18}$ While in some states the distinction between sealed and unsealed instruments has been abolished by statute, ${ }^{19}$ other states still maintain the

${ }^{15}$ Keppell v. Bailey, 2 Myl. \& K. 517 (Eng. 1834). But see Luker \& Dennis, 7 Ch. Div. 227,236 (1876).

${ }^{18}$ I9 N. J. Eq. 537, aff'g I8 N. J. Eq. 337 ( 1868 ) ; see Nat'l Union Bank v. Segur, 39 N. J. L. 173, I84 (I877).

${ }^{17}$ Supra note 16, at 547 .

${ }^{28}$ Finley v. Simpson, 22 N. J. L. 31 I (1850); Hagerty v. Lee, 54 N. J. L. 580, 25 Atl. 319 (1892); McNichol v. Townsend, 73 N. J. Eq. 276, 67 Atl. 938 (I907), aff'd, 74 N. J. Eq. 6r8, 70 Atl. 965 (I908); Brigham v. Mulock Co., 74 N. J. Eq. 287, 70 Atl. I85 (1908); Newbery v. Barkalow, 75 N. J. Eq. 128, 71 Atl. 752 (I908).

${ }^{19}$ Deyer v. Gill, 32 Ark. 4Io (I877); Ortman v. Dixon, 13 Cal. 33 (1859); Edwards v. Dillon, I47 Ill. I4, 35 N. E. I35 (I893); Williams v. Haines, 27 Iowa 251 (I869); Gibbs v. McGuire, 70 Miss. 646, I2 Ś. 829 (1893); Landauer v. Sioux Falls Imp. Co., io S. D. 205, 72 N. W. 467 (1897); Garrett v. Belmont Land Co., 94 Tenn. 459, 29 S. W. 726 (1894); Murray v. Beal, 23 Utah 548, 65 Pac. 726 (I901). 
ancient rule. ${ }^{20}$ In the former group of states, no question of the common law liability of a grantee under a deed poll as a covenantor can arise. His liability is in an action of debt or assumpsit, or an implied covenant. In New Jersey, the grantee of a deed, by accepting it, becomes liable on the covenants therein purporting to be made by him, as if he had signed and sealed the instrument. ${ }^{21}$ Hence a covenant by the grantee to assume a mortgage, for the payment of which the grantor is personally responsible, binds the grantee to pay the mortgage debt. ${ }^{22}$ The damages that may be recovered by the grantor are the full amount of the debt, even though he has not yet paid it. ${ }^{23}$

A covenant need not have the precision of form required in former days. Any words that clearly express the intention of the covenantors will be sufficient. ${ }^{24}$ A covenant that the grantor "will warrant and forever defend the premises against all lawful claims freed and discharged of all encumbrances", is not only a covenant against encumbrances, but is also a general warranty. ${ }^{25}$ Likewise the purpose of a grantor, with whom a restrictive covenant is made, can be evidenced by the language in the covenant itself, or by other language in the deed. ${ }^{26}$ The importance of the use or omission of the word assigns still lingers in some judicial minds. The confusing, if not contradictory, resolutions in Spen-

${ }^{20}$ Hinsdale v. Humphrey, 15 Conn. 43I (1843); Dawson v. Western Md. R. R., I07 Md. 70, 68 Atl. 301 (1907); Parish v. Whitney, 69 Mass. 516 (1855). Contra: Atlanta, K. \& N. Ry. v. McKinney, 124 Ga. 929, 53 S. E. 701 (1906); Sexauer v. Wilson, 136 Iowa 357, 113. N. W. 941 (1907); Poage v. Wabash, St. L. \& P. Ry., 24 Mo. App. I99 (I887); Burbank v. Pillsbury, 48 N. H. 475 (1869); Atlantic Dock Co. v. Leavitt, 54 N. Y. 35 (1873); Bowen v. Beck, 94 N. Y. 86 (1883) ; Blood v. Crew-Levick Co., I77 Pa. 606, 35 Atl. 871 (1896); Beedy v. Nypano R. R., 250 Pa. 5I, 95 Atl. 343 (I9I5).

${ }^{21}$ Sparkman v. Gove, 44 N. J. L. 252 (1882).

2 Ibid.

${ }^{2}$ Ibid.

"Davis v. Lyman, 6 Conn. 249, 252 (1826) ; Kettle River R. R. v. Eastern Ry., 4I Minn. 46I, 47I, 43 N. W. 469,473 (I889); Langdon v. Mayor of New York, 93 N. Y. I29, 150 (1883); Masury v. Southworth, 9 Ohio St. 340,348
(1859).

$\approx$ Carter v. Denman, supra note I.

${ }^{90}$ Hemsley v. Marlborough Hotel Co., 62 N. J. Eq. I64, 50 Atl. I4 (190I), aff'd, 63 N. J. Eq. 804, 52 Atl. Ir30 (I902); Rogers v. Hosegood, [I900] 2 Ch. 388 . 
cer's Case ${ }^{27}$ have darkened rather than lightened the path of inquiry. The modern decisions are far less confusing. If a covenant does not touch or concern the land, but is merely collateral, it is personal, ${ }^{28}$ even though the covenanting parties have clearly expressed their intention that the covenant should run with the land. ${ }^{29}$ On the other hand, if the covenant does touch or concern the land, whether or not it pertains to a thing in esse, the use of the word assigns is not essential for the covenant to run with the land. ${ }^{30}$ Its omission is simply evidence of the intention of the covenantors, but is not decisive. ${ }^{31}$ A covenant in which a lessor covenants with the lessee, without mentioning the lessee's assigns, to pay for the value of substituted machinery at the end of the term, enures to the benefit of the assignee of the tenant. Such improvements are a lien on the premises, which equity will enforce. ${ }^{32}$

If it be doubtful whether a clause in a deed is intended as a covenant or as a condition, the clause should be construed as a covenant, for the legal consequences of a broken condition are much greater than those of a broken covenant. ${ }^{33}$ In like manner, words in a deed, not in the form either of a covenant or a condition, will be construed as a covenant rather than as a condition. ${ }^{34}$

Since the covenant runs with the land, it is immaterial whether it pass by a deed from the grantor or from a judicial officer properly authorized to convey it. By statute a sheriff's deed passes all the interest of the mortgagor at the date of the mortgage, or, if made under a judgment at law, the deed passes

${ }^{27} 5$ Coke 16 (Eng. 1582 ).

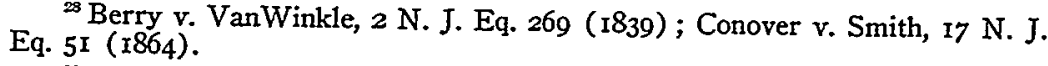

${ }^{20}$ Ibid.

${ }^{30}$ Woodruff v. Trenton Water Power Co., Io N. J. Eq. 489 (1856); see Winfield v. Henning, 21 N. J. Eq. 188, I89 (I870); Note (1907) I4 L. R. A.
(N. s.) I85. (1899).

${ }^{31}$ See Brown v. Southern Pac. Ry., 36 Ore. 128, I35, 58 Pac. I104, I107

s: Copper v. Wells, I N. J. Eq. ro (1830) ; Conover v. Smith, supra note 28.

3 Woodruff v. Woodruff, 44 N. J. Eq. 349, I6 Atl. 4 (I888).

"Ibid. 
all his interest at the time of its rendition. ${ }^{35} \mathrm{He}$ is as much the assignee of the covenant as though the conveyance was made by the covenantee himself. ${ }^{36}$

Moreover, an assignee who is evicted may maintain a personal action of covenant against the executors of the grantor. ${ }^{37}$ He need not aver that notice of the pendency of the suit, which effected the plaintiff's eviction, was given to the defendant; $;^{3 s}$ nor need he be described as assignee. ${ }^{39}$ The declaration must, of course, describe the land with convenient certainty.

While the courts must determine, as a matter of law, whether a covenant does touch and concern the land, they regard with more favor than formerly the interpretation put by covenantors on their engagements. Chief Justice Beasley said:

". . . while it is plain that a mere personal covenant cannot, by the agreement of parties, have its nature so altered as to make it transmissible with land, nevertheless when the question is whether the given covenant does concern certain premises, the fact that such parties considered it to have such quality, should be potent in a decision of the inquiry." 40

The covenant by the vendor in this case, attached to a deed of land and a bank building thereon, was that he would not engage in the business of banking in that locality. This was regarded as a benefit to the estate conveyed and ran with the land.

After a breach of the covenant of warranty it no longer runs with the land, but becomes a mere chose in action. By the ancient law this was not assignable, ${ }^{41}$ but it is now by statute. ${ }^{42}$ If the land is sold after a breach of the covenant, the right of action does not pass to the purchaser; it still belongs to the owner

s Carter v. Denman, supra note I.

${ }^{30}$ Carter v. Denman, supra note I, at 272; McCrady v. Brisbane, I Nott \& McC. I04 (S. C. 18I8).

${ }^{37}$ Chapman v. Holmes, supra note I.

"Ibid.

${ }^{30}$ Carter v. Denman, supra note I.

${ }^{10}$ Nat'l Union Bank v. Segur, supra note 16, at 187.

'DeLong v. Spring Lake Imp. Co., 74 N. J. L. 250, 66 Atl. 59i (1907).

${ }^{2}$ N. J. Comp. Stat. (19io) p. 1965, $\$ 38$. 
at the time the breach occurred. ${ }^{43}$ The right of action does not arise unless there has been either eviction by title paramount or action brought; ${ }^{44}$ nor does the mere existence of a right to recover nominal damages on a covenant against encumbrances prevent a recovery of substantial damages on a covenant of warranty after a subsequent eviction. ${ }^{45}$ While a cause of action for breach of a covenant against encumbrance is separate and distinct from a cause of action for a breach of warranty, the two covenants may be in the same instrument. ${ }^{46}$ Again, though a deed is inter partes, a covenant therein made with a third person may be enforced by him if it clearly appears that it is the intention of the parties to confer this right; ; $^{4}$ formerly this right was denied him. ${ }^{48}$

Before considering the relief afforded by courts of equity to parties who have entered into covenants running with land, some discussion of the principles of implied covenants is necessary. If land conveyed is located by a highway, in equity there is an implied covenant that the land in the highway, subject to the public easement, is appurtenant to that specified in the deed of conveyance. This conception of an implied covenant has been fully set forth by Vice-Chancellor Van Fleet, in Coudert v. Sayre:

“. . . when it appears by the true construction of the terms of a grant that it was the well-understood purpose of the parties to create or reserve a right, in the nature of a servitude or easement, in the property granted, for the benefit of other land owned by the grantor, no matter in what form such purpose may be expressed-such right, if not against public policy, will be held to be appurtenant to the land of the grantor, and binding on that conveyed to the grantee ...

${ }^{* 3}$ DeLong v. Spring Lake Imp. Co., stpra note $4 \mathrm{I}$.

"Carter v. Denman, supra note I.

${ }^{45}$ Smith v. Wahl, 88 N. J. I. 623, 97 Atl. 26r (I915). But $c f$. Leggett v. Lippincott, 50 N. J. L. 462 , I4 Atl. 577 (1888).

${ }^{46}$ Smith v. Wahl, supra note 45.

${ }^{47}$ Nat'l Union Bank v. Segur, supra note 16.

${ }^{4}$ Smith v. Emery, 12 N. J. L. 53 (1830).

46 N. J. Eq. 386, 395, I9 At1. I90, I93 (1890); cf. Kirkpatrick v. Peshine, 24 N. J. Eq. 206 (1873); Hayes v. Waverly \& P. R. R., 5 I N. J. Eq. 345, 27 Atl. 648 (1893); Bowen v. Smith, 76 N. J. Eq. 456, 74 Att. 675 (I909); Brewer v. Marshall, supra note 16. 
The right and burden thus created pass with the land to all subsequent grantees, and every grantee of land to which such right is appurtenant is entitled in equity to protection, "notwithstanding that his right may not rest on a covenant which, as a matter of law runs with the title to his land..." so

Equity extends its protecting wings in another direction. Even though a covenant may not run with the land, or an easement relation may not exist, equity will compel the performance of a covenant known to the party who in justice ought to perform it. $^{51}$ After reviewing several decisions in which relief was granted, Chief Justice Beasley, in Brewer v. Marshall, ${ }^{52}$ remarked that the courts proceed on the principle of preventing a party having knowledge of the rights of another from defeating them. Consequently: ". . . a court of equity will sometimes impose the burden of a covenant relating to lands on the alienee of such lands on a principle altogether aside from the existence of an easement or the capacity of such covenant to adhere to the title." 53

A still more important application of this principle occurs in the many cases involving land improvement schemes. ${ }^{54}$ The most general principle applied to them was formulated, in the familiar Monmouth Beach case, by Vice-Chancellor Green:

${ }^{50}$ Coudert v. Sayre, supra note 49 , at 395 , I9 Atl. at I94.

"2. Whitney v. Union Ry., 77 Mass. 359 ( 1858 ) ; Parker v. Nightingale, 88 Mass. $34 \mathrm{I}$ (1863); Kettle River R. R. v. Eastern R. R., supra note 24; Brewer v. Marshall, supra note 16; Columbia College v. Lynch, 70 N. Y. 440 (1877); Hodge v. Sloan, I07 N. Y. 244, I7 N. E. 335 (1887) ; Horn v. Miller, 136 Pa. 640,20 Atl. 706 (I890); Bald Eagle Valley R. R. v. Nittany Valley R. R., I7I Pa. 284, 33 Att. 239 (I895) ; Middletown v. Newport Hospital, 16 R. I. 319, I5 Atl. 800 (I888).

${ }^{62}$ Sttpra note 16 , at 544 .

${ }^{*}$ Brewer v. Marshall, supra note 16, at 544; Holsman v. Boiling Spring Bleaching Co., I4 N. J. Eq. 335 (1862); Van Doren v. Robinson, 16 N. J. Eq. 256 (1863) ; Kirkpatrick v. Peshine, supra note 49 ; Franklin v. Creth, 97 N. J. Eq. 538, I28 Atl. 268 (1925); Tulk v. Moxhay, 2 Phill. 774 (Eng. 1848); $c f$. Leaver v. Gorman, 73 N. J. Eq. 129, 67 Atl. III (1907); Hyman v. Tash, 7I Atl. 742 (N. J. Eq. I908).

a Winfield v. Henning, supra note 30; Mulligan v. Jordan, 50 N. J. Eq. 363, 24 At1. 543 (1892); Hayes v. Waverly \& P. R. R., supra note 49; Trout v. Lucas, 54 N. J. Eq. 36I, 35 Atl. I53 (I896); Morrow v. Hasselman, 69 N. J. Eq. 6r2, 6r Atl. 369 (1905) ; Barton v. Slifer, 72 N. J. Eq. 812, 66 Atl. 899 (1907); McNichol v. Townsend, supra note 18; Leaver v. Gorman, supra note 53; Newbery v. Barkalow, supra note 18; Bowen v. Smith, supra note 49; Miller v. Jersey Coast Resorts Corp., 98 N. J. Eq. 289, I30 Atl. 824 (I925); see Polhemus v. DeLisle, 98 N. J. Eq. 256, 262, I30 Atl. 618, 621 (1925). 
“. . . a court of equity will restrain the violation of a covenant, entered into by a grantee, restrictive of the use of lands conveyed, not only against the covenantor but against all subsequent purchasers of the land with notice of the covenant, irrespective of the questions whether the covenant is of a nature to run with the land or whether it creates an easement; provided, however, that its enforcement is not against public policy." 55

"Restrictions of this character", said Chief Justice Depue, "are valid, and are regarded as for the benefit of the owners of the tract to be improved and made profitable by sales of lots, and also for the advantage of persons who have become purchasers on the faith of the scheme of improvement . . " 56

In applying this principle, therefore, the right of the owner of a lot to enforce a restrictive covenant, on the use of another lot, entered into between former owners, depends primarily on whether the covenant was made for the benefit of the land embraced in the owner's lot. While this can be done in equity, in law the purchaser of one of such lots from the grantee could not enforce the covenant against the purchaser of another of them. ${ }^{57}$ The common scheme, to be effective in equity, must be strictly preserved. ${ }^{58}$ It must be universal and reciprocal. The same restrictions must be imposed upon all lots similarly situated. If they are not alike, or some lots are not subject to restrictions, while others are, the scheme fails.

"It is only when there is a general plan imposed upon the lands sold, under which each purchaser buys, that a prior purchaser may enforce the restriction against a subsequent purchaser who violates it." 59

${ }^{3}$ DeGray v. Monmouth Beach Club House Co., 50 N. J. Eq. 329, 332, 24 Atl. 388, 389 (1892); $c f$. Spicer v. Martin, I4 App. Cas. 12 (I889); Elliston v. Reacher, [rg08] 2 Ch. 374, aff'd, ibid., 665; see Renals v. Cowlishaw, 9 Ch. D. 125, I28, aff'd, II Ch. D. 866 (1879).

${ }^{5 e}$ Walker v. Renner, 60 N. J. Eq. 493, 498, 46 Atl. 626, 626 (1900).

${ }^{87}$ See Winfield v. Henning, supra note 30 , at 190 .

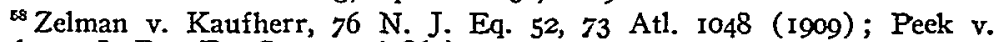
Matthews, L. R. 3 Eq. Cas. 515 (1867).

${ }^{6}$ Ocean City Ass'n v. Headley, 62 N. J. Eq. 322, 336, 50 Atl. 78, 83 (I90I); $c f$. Mulligan v. Jordan, supra. note 54; Ryall v. Saxe, 97 N. J. Eq. 393, I29 Atl. 433 (1925); Klein v. Sisters of Charity, r39 Atl. 174 (N. J. Eq. 1927). 
A covenant or agreement restricting the use of land in favor of other lands creates an easement that makes one of the lands subservient and the other dominant.

"All that is necessary", says Chief Justice Gummere, "to create such an easement is a clear manifestation of the intention of the person who is the source of title to subject one parcel of land to a restriction in its use for the benefit of another, and efficient language to make that restriction perpetual." 60

Again, a covenant prescribing the mode of improving land, and restraining the use of it, does not violate any rule of law when the restriction is reasonable, and the party in whose favor it is made, or those in privity with him, is interested in the subject matter of the restriction. ${ }^{61}$ A restriction may therefore be applied to land used and operated as an elevated railroad. ${ }^{62}$

Moreover, if, in a general land improvement scheme, some of the lots are set apart for specified purposes, such as parks, which are regarded as an advantage to all purchasers of lots, there is an implied covenant with them that such lots shall retain their special character. ${ }^{63}$ Each purchaser of a lot, or his grantees, may enforce the easement against the grantor, or his grantees who purchased with notice of the implied covenant. ${ }^{64} \mathrm{He}$ may also enforce it against the donee of the covenantor who accepts as a gift a conveyance of part of the land charged with the covenant. ${ }^{65}$ On the other hand, one who divides his land into lots and streets as shown by a public map, if no neighborhood scheme exists calling

Restrictions in the conveyance must be incorporated by the common grantor in every deed to the lots sold under the general scheme. Ferraro v. Zozlowski, 138 Atl. I97 (N. J. Eq. 1927).

${ }^{\circ}$ Propper v. Colson, 86 N. J. Eq. 399, 401, 99 Atl. 385, 386 (I9r6).

${ }^{61}$ See Grigg v. Landis, 2I N. J. Eq. 494, 502 (I870).

" Hayes v. Waverly \& P. R. R., supra note 49.

${ }^{e s}$ Lennig v. Ocean City Ass'n, 4I N. J. Eq. 606, 7 Atl. 49I (I886) ; Bridgewater v. Ocean City R. R., 62 N. J. Eq. 276, 49 Atl. 801, aff'd, 63 N. J. Eq. 798, 52 Atl. II30 (1902).

a Ibid.

« Bridgewater v. Ocean City R. R., supra note 63. 
for the erection of one building only on a lot, does not impliedly covenant that he will not subdivide the lots into smaller parcels. ${ }^{66}$

Finally, restrictions in a general land improvement scheme may in equity be imposed on lands beyond the express restrictions contained in deeds to purchasers, on the theory of an implied covenant. $^{67}$

By way of further defining the rights of covenanting parties, in a plan forming a general land scheme, Vice-Chancellor Grey has remarked that:

"The parties who may enforce such restrictive covenants are the original grantors with whom they were made, and all subsequent purchasers of the lands to be benefited by them. The parties against whom they may be enforced are the grantees who accept deeds containing the restrictions, and all those who subsequently purchase the restricted lands with notice of the covenant." 68

Consequently if an owner sells a portion of his land with a covenant restricting its use, a subsequent grantee of another portion from the same owner may enforce the covenant against the original grantee and against all subsequent purchasers with notice from him. ${ }^{69}$ On the other hand, a prior purchaser from the original owner cannot enforce a restriction imposed by the latter upon a lot subsequently conveyed, unless in the prior deed there was a grant of a right in the residue of the land retained by the vendor ${ }^{70}$ or a stipulation that the restrictions put upon the lot sold by the prior deed should also be imposed upon the remaining property when making sales to subsequent purchasers, or in some other way indicating that all the lots sold are parts of a uniform

${ }^{6}$ Farquharson v. Scoble, 38 Cal. App. 680, I77 Pac. 310 (I918); Utujian v. Boldt, 242 Mich. 33I, 218 N. W. 692, 57 A. L. R. 761 (1928); Stoever v. Gowen, $280 \mathrm{~Pa} .424$, I24 Atl. 684 (I924); Herold v. Columbia Investment Co., 72 N. J. Eq. 857,67 Atl. 607 (I907); cf. Schickhaus v. Sanford, 83 N. J. Eq. 454, 9 I Atl. 878 (1914).

ot Shickhaus v. Sanford, supra note 66; Lennig v. Ocean City Ass'n, supra note 63; Herold v. Columbia Investment Co., supra note 66; Talmadge v. East River Bank, 25 N. Y. I05 (1862).

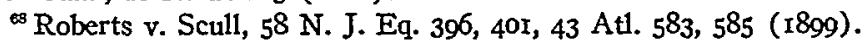

${ }^{\infty}$ Ibid.

${ }^{20}$ Ibid. 
scheme. ${ }^{71}$ Again, a grantee, whose deed is subsequent to the imposition of a restrictive covenant on land of the grantor, can enforce the covenant against a prior grantee of another lot, but a prior grantee can only enforce it where the purpose of the covenant is to carry out a general plan or scheme for the development of all the original grantor's property. ${ }^{72}$

The right to enforce a restriction in a deed, made for the benefit of the vendor's remaining land, passes to a subsequent grantee of the vendor..$^{73}$ But if a deed containing a restrictive covenant is made subsequent to a deed of other property owned by the same vendor, the grantee in the prior deed does not take the land with the benefit of such restrictive covenant. ${ }^{74}$

"There can be little, if any, difference in principle", says Vice-Chancellor Leaming, "between a restrictive covenant made by a vendee for the benefit of remaining land of his vendor, and one made by a vendor touching his remaining land for the benefit of his vendee. Both are held to be enforceable by a purchaser of the land, for the benefit of which the covenant has been made, against a purchaser of the restricted land who is chargeable with notice of the covenant." 75

Furthermore, if in a land improvement scheme, a mortgage is created containing the covenant that, after part payment, a part of the land mortgaged may be released, the benefits of the covenant should be regarded as running with the land and passing with it to a grantee of the mortgagor, even though it is not specifically stated that the covenant is for the benefit of the assigns of the mortgagor. ${ }^{\text {i6 }}$

The original grantor, in imposing a covenant upon the grantee, may or may not bind himself. If he does not, the grantee, having no right of action against him, cannot pursue any other

${ }^{71}$ Ibid.

I Ibid.

${ }^{73}$ Hemsley v. Marlborough Hotel Co., supra note 26.

"Ibid.

${ }^{75}$ Wootton v. Seltzer, 83 N. J. Eq. 163, 167, 90 Atl. 70I, 703 (19r4).

${ }^{76}$ Ventnor Investment Co. v. Record Development Co., 79 N. J. Eq. I03, 80 Atl. 952 (I9II). 
grantee to whom the grantor may convey the whole, or a part, of the remaining land. Again, after a deed has been made, the grantee cannot get the benefit of restrictions which the grantor has seen fit to insert in subsequent conveyances. ${ }^{77}$

A covenant restricting the lawful use of land by the owner must be strictly construed; ${ }^{78}$ doubtful restrictions will not be enforced. ${ }^{79}$ They must be clear and unambiguous; ${ }^{80}$ otherwise the courts will refuse to enforce them. ${ }^{81}$ An exception, limiting the scope and effect of a restrictive covenant, should have a liberal construction. $^{82}$ An exception may in some instances have the practical effect of enlarging, by explaining, an otherwise ambiguous restrictive covenant, or one of doubtful meaning. Its ordinary province is to limit or detract from, rather than to enlarge, the scope of the covenant to which it is attached. ${ }^{83}$ Of course, an injunction will not be granted if no restrictive covenant exists. ${ }^{84}$

A common grantor, who has parted with the title to a portion of his land, for the benefit of which a restrictive covenant had been imposed on other land previously conveyed by him, cannot thereafter release or modify the covenant, to the injury of the grantee of the benefited property. ${ }^{85}$ In other words, a grantor's release of a restrictive covenant does not preclude other parties, to whom he had conveyed lots, from enforcing their rights against any purchaser violating the restriction. ${ }^{86}$

"Seidel v. Mills, 84 N. J. Eq. 285,96 Atl. 899 (I9I5).

${ }^{78}$ Fortesque v. Carroll, 76 N. J. Eq. 583, 75 Atl. 923 (I9Io) ; Howland v. Andrus, 8I N. J. Eq. I75, 86 Atl. 391 (IgI2); Ronan v. Barr, 82 N. J. Eq. 563, 89 Atl. 282 (1913); Jones v. Mulligan, I2I Att. 608 (N. J. Eq. I923); Trainer v. Calef, 96 N. J. Eq. 657,126 At1. 301 (I924).

${ }^{70}$ McNichol v. Townsend, supra note I8; see Catoggio v. Rehm, 83 N. J. Eq. 327, 329, 90 Atl. 1047, 1048 (I914).

${ }^{8}$ Goater v. Ely, 80 N. J. Eq. 40, 82 Atl. 61 I (Igr2) ; Meaney v. Stork, 80 N. J. Eq. 60, 83 Atl. 492 (IgI2); Holman v. Parker, 94 N. J. Eq. 4 I, II 8 Atl. 334 (I922); Tsangas v. Broogos, 95 N. J. Eq. 499, 123 Atl. 247 (1924).

${ }^{81}$ Camovito v. Matthews, 82 N. J. Eq. 218, 88 Atl. I87 (I913); Underwood

v. Herman \& Co., 82 N. J. Eq. 353, 89 Atl. 2I (I913).

Trainer v. Calef, supra note 78 .

\$homas v. Hillman, I00 N. J. Eq. 328, 134 Atl. 655 (1926).

Bs Beattie v. Howell, 98 N. J. Eq. I63, I29 At1. 822 (I925).

$\$$ Bowen v. Smith, supra note 49; Coudert v. Sayre, supra note 49.

st Henderson v. Champion, 83 N. J. Eq. 554, 91 Atl. 332 (I9r4); Muller v. Weiss, 91 N. J. Eq. 29, 108 Atl. 768, aff'd, 91 N. J. Eq. 321, 109 Atl. 357 (1919); Wootton v. Seltzer, supra note 75. 
A restrictive covenant may be abandoned. This is a favorite defense of transgressors who seek to destroy or terminate restrictions. The equitable right to enforce them may be lost by a degree of acquiescence in their violations amounting to an abandonment of the right of enforcement. ${ }^{87}$ If in a general or neighborhood scheme, the parties in interest, by express acts or passive acquiescence, permit such violations of the plan or scheme as destroy, wholly or partially, the benefit from it, they absolve each other, to a corrésponding extent, from its burdens. ${ }^{88}$ It is the mutual benefit accruing to all and to each which makes it inequitable for any one so benefited to repudiate the burden, to the injury of the others. ${ }^{89}$

How many violations of restrictions will operate as an abandonment? The inquiry in each case evidently is largely an isolated one. It has been held that several violations of a covenant, which in no substantial way affected the value and worth of the property, were no indication of the abandonment of a general scheme of land improvement. ${ }^{90}$ A few violations of a restrictive covenant has often been held to be no bar to injunctive relief. ${ }^{91}$ Indeed, a small number of violations in a large scheme of development has been regarded as indicative of a general adherence to the plan. ${ }^{22}$

On the other hand, a covenantee may not enforce in equity a restrictive covenant in a general land improvement scheme, after he has failed to exercise the right for a considerable time, and many buildings have been erected contrary to the provisions of the covenant. The covenantee's remedy is then limited to an action at law. ${ }^{93}$ Moreover, an injunction will not be issued to a

${ }^{87}$ Chelsea Land \& Imp. Co. v. Adams, 7I N. J. Eq. 771, 66 Atl. 180 (I906) ; Fort v. Field, 124 Atl. 3 I4 (N. J. Eq. I923); Bowen v. Whilldin, 98 N. J. Eq. I40, 130 Atl. I (I925); Bowen v. Smith, supra note 49.

${ }^{3}$ See Sanford v. Keer, 80 N. J. Eq. 240, 244, 83 Atl. 225, 227 (Igr2).

${ }^{80}$ See Sanford v. Keer, supra note 88, at 244,83 Atl. at 227.

${ }^{\infty}$ Newbery v. Barkalow, supra note 18; Barton v. Slifer, supra note 54 .

${ }^{\circ}$ Polhemus v. DeLisle, supra note 54.

$\approx$ See Polhemus v. DeLisle, supra note 54, at 271 , 130 Atl. at 624.

${ }^{\infty}$ Ocean City Ass'n v. Schurck, 57 N. J. Eq. 268, 4I Atl. 914 (1898); Ocean City Ass'n v. Headley, supra note 59 ; Ocean City Land Co. v. Weber, 83 N. J. Eq. 476, 91 Atl. 600, aff'd, 84 N. J. Eq. 505, 94 Atl. II02 (I915); Roper v. Wil- 
grantor to restrain the violation of a covenant against doing business on Sunday, when it has been openly violated for several years by the defendant grantee and by other grantees of the same grantor. ${ }^{94}$

In abandoning restrictions, several questions arise: First, what action by the original owner of lots will have the effect of an abandonment? If he knowingly permits some of the grantees to violate the restrictions, which are intended to conserve the general purpose of the scheme, he cannot enforce them against one grantee. $^{95}$ The building of a few bay windows over the line does not work an abandonment. ${ }^{96}$ In one of the cases, the complainant and his predecessor owned lots on which there was a restrictive building line. The restriction was incorporated in the deeds of more than one hundred and fifty purchasers, one hundred of whom had violated it. No action was taken to enforce the restriction, save on a single occasion. It was held that the plan had been abandoned and could not be enforced. Said Vice-Chancellor Bergen :

"I think that all persons occupying these lands are entitled to be treated alike, and this complainant company cannot undertake to waive violations of these restrictions in so universal a manner as it is proved has been done here, and then undertake to enforce it against one other of their purchasers. Such a general consent to the non-observance of restrictive covenants amounts to an abandonment of the original intention and design with regard to restrictions." 97

Again, when a plan of restrictions has been so changed by altering them in subsequent deeds, for lots similarly located, that the enforcement of the original restrictions would be a burden on the restricted lots, without conferring any appreciable benefit on

liams, I Turn. \& Russ. I8 (Eng. I822); Peek v. Matthews, L. R. 3 Eq. 5 I5 (1867); cf. Woodbine Land \& Imp. Co. v. Riener, 72 N. J. Eq. 787, 65 Atl. 1004 ( 1907$)$.

os Ocean City Ass'n v. Chalfont, 65 N. J. Eq. I56, 55 At1. 8or (I903); Ocean City Ass'n v. Schurck, supra note 93.

${ }^{25}$ Chelsea Land \& Imp. Co. v. Adams, supra note 87.

${ }^{\infty}$ Morrow v. Hasselman, supra note 54 .

${ }^{97}$ Chelsea Land \& Imp. Co. v. Adams, supra note 87, at 773, 66 Atl. at I8I. 
the lots of those seeking to enforce them, equity will decline to act.

On the other hand, if some of the grantees violate them without the grantor's knowledge, his right to enforce the restrictions is not lost. The effect of his conduct with respect to the known or unknown violation of them can hardly be determined by precedent, but rather by inquiry whenever the question arises. This much is doubtless true, that:

"Where the restrictions are not universal, or after frequent violation of the restrictions have been permitted, then the neighborhood scheme will be considered abandoned." 98

The second question is: What action by the grantees may work an abandonment of the scheme? Evidently one owner of lots cannot accomplish this purpose. How many must conspire to effect this end? In other words, can such a scheme be disrupted by the action of any number of the lot owners less than all of them; and if so, how many, by their combined action, whether acting in concert or individually, can do it? Surely the original owner of a land improvement scheme cannot abandon or release any restrictions he may have imposed for the benefit of all subsequent purchasers of lots, without their acquiescence. ${ }^{99}$ Clearly, a complainant is not estopped from opposing the erection of a garage that is within a restriction, because other lot owners in the vicinity, subject to the same restriction, violated their covenant. ${ }^{100}$ Thus $A$ was a resident in a land scheme which prohibited flat roofs on any buildings. Notwithstanding the restriction, many of them had flat roofs, and $A$ knew of the restriction. Its violation by others did not justify $A$ in violating it, and as the complainant acted promptly, $A$ was required to comply with the restriction. ${ }^{101}$

It may be difficult in some cases to decide whether there has been a known and wilful violation of a restrictive covenant, or

${ }^{88}$ Scull v. Eilenberg, 94 N. J. Eq. 759, 763, I21 At1. 788, 790 (1923); see Laverack v. Allen, I30 Atl. 6I5, 6I6 (N. J. Eq. I924).

${ }^{\infty}$ Barton v. Slifer, supra note 54 .

${ }^{100}$ Kumble v. Jaffee, I00 N. J. Eq. 290, 134 At1. 673 (1926).

${ }^{102}$ Durham Essex Corp. v. Schaffer, 99 N. J. Eq. 602, I33 Atl. 754 (I926). 
simply an innocent mistake. In the latter case, damages are regarded as an adequate compensation for the wrong, and a mandatory injunction will not be granted. ${ }^{102}$ Again, if the benefits of restrictions on lots forming a land improvement scheme are partly or totally destroyed by violation of the plan or restrictions, the accompanying burden is correspondingly modified. ${ }^{103}$ However, when changes do not conflict with the essential purpose of the plan and covenants, the benefit is unimpaired, and a violation of the restrictions will be enjoined. ${ }^{104}$

A restrictive covenant outside a general land scheme will not be enforced when the grantor himself has manifested a disregard of its provisions, and intends to abandon it. ${ }^{105}$ Thus the Duke of Bedford, after imposing restrictions on the use of land sold by him, violated the spirit and intent of his covenant by erecting a greenhouse and dwelling on the land retained. Lord Eldon would not enforce the covenant against the other party, after such a plain violation of its spirit and intent by the Duke himself. ${ }^{106}$

An abandonment may be effected by such a change in the condition of the neighborhood, after the adoption of the scheme, that its original purpose can no longer be continued. ${ }^{107}$ The well known Thacher case is perhaps the pioneer in establishing this rule. ${ }^{108}$ A change in the use of a part of the land which is subject to restrictions does not have the effect of destroying them on the remainder. ${ }^{109}$

A covenanting party, to be bound by restrictions, must have notice of them. When he has such notice, he cannot avoid their

${ }^{103}$ Bauby v. Krasow, 107 Conn. 109, I39 Atl. 508, 57 A. L. R. 33I (1927).

${ }^{103}$ Roper v. Williams; Peek v. Matthews, both supra note 93.

${ }^{20}$ Trout v. Lucas, supra note 54; Ocean City Ass'n v. Headley, supra note 59; Sanford v. Keer, supra note 88.

${ }^{105}$ Page v. Murray, 46 N. J. Eq. 325, ig Atl. II (1890).

${ }^{200}$ Duke of Bedford v. Trustees of British Museum, 2 Myl. \& K. 552 (1822).

${ }^{100}$ Fisher v. Griffith Realty Co., 88 N. J. Eq. 204, 10I Atl. 4II (1917) ; Page v. Murray, supra note 105; Starkey v. Gardner, I94 N. C. 74, i38 S. E. 408,54 A. L. R. 806 (1927) ; $c f$. Sandusky v. Allsop, 99 N. J. Eq. 6r, 13I Atl. 633 (1926).

${ }^{208}$ Trustees of Columbia College v. Thacher, 87 N. Y. 31 I (I882).

${ }^{100}$ Landell v. Hamilton, 175 Pa. 327, 34 Att. 663 (1896) ; Phillips v. Donaldson, $269 \mathrm{~Pa} .244$, 112 Atl. 236 (1920). 
proper effect. ${ }^{110}$ The notice may be sufficient though contained in an unrecorded deed. ${ }^{111}$ The record of a deed, containing a restrictive building covenant, is notice to all persons to whom the grantee's title subsequently passes. ${ }^{112}$ By statute, a recorded deed is a complete notice of its execution and contents to all subsequent purchasers. ${ }^{113}$ The vendor of a lot who takes advantage of the vendee, by intentionally keeping him in ignorance of a restriction against erecting an apartment house, is rightfully denied specific performance of the sale. ${ }^{114}$

A violator of a restriction cannot afterward be rescued from his wrongdoing by the action of his accommodating grantor in giving him another deed modifying the first and which, if valid, would relieve him. Such belated action is ineffective to undo the wrong. ${ }^{115}$ In Polhemus v. De Lisle ${ }^{116}$ the court declared that the common grantor of lots, subject to a restrictive covenant, was without the least shred of authority or right to release or modify the covenant so far as it operated to confer a benefit on land which he had previously conveyed, or, by his own interpretation, to modify the plain meaning of the restrictive covenant imposed upon all lots in the tract.

Another defense, when all others fail, is that the complainant has been sleeping on his right. This, in most cases, has very little merit, ${ }^{117}$ although on a few occasions the complainant has acted too late. ${ }^{118}$ Action must be taken before the violator has

${ }^{100}$ DeRossett v. Bianchi, 100 N. J. Eq. 439, I36 Atl. 301 (1927).

11 Wahl v. Stoy, 72 N. J. Eq. 607, 66 Atl. 176 (1907).

112 Bowen v. Smith, stipra note 49 ; Hayes v. Waverly \& P. R. R, stipra note 49.

${ }^{113}$ N. J. Comp. Stat. (I9I0) p. 1552, § 53.

124 Muller v. Weiss, 91 N. J. Eq. 29, 108 Atl. 768, aff'd, 9r N. J. Eq. 321, 109 Atl. 357 (1920).

${ }^{215}$ Laverack v. Allen, supra note 98 ; Wahl v. Stoy, supra note III.

${ }^{110}$ Supra note 54, at 268, 130 Atl. at 623 .

${ }^{17}$ Lignot v. Jaekle, 72 N. J. Eq. 233, 65 Atl. 221 (1906) ; Heyniger v. Levinsohn, 87 N. J. Eq. 47I, IOI Atl. I89, $a f^{\prime d}$, 88 N. J. Eq. 34I, IO2 Atl. 63I (I9I7); Lamonte v. Orlando, 97 N. J. Eq. 425, I29 Atl. 442 (I925); Goater v. Ely, supra note 80.

${ }^{228}$ DeGama v. D'Aquila, ror Atl. 1028 (N. J. Eq. 1917) ; Trout v. Lucas, supra note 54 
expended much money. ${ }^{119}$ The complainant must not knowingly permit large expenditures and remain silent, especially after many buildings have been erected contrary to the provisions of the covenant. ${ }^{120} \mathrm{He}$ must act promptly. ${ }^{121}$ Since owners are entitled to the benefit of restrictions at the time of their violation, they may apply for relief, but their grantees may be barred by acquiescence in the violation, or by delay in enforcing their rights. An unexplained delay for several years is fatal. ${ }^{22}$

The right to enforce a building restriction, incorporated in all the deeds given by the owners of a general land improvement scheme, enures to all grantees as members of a class, and they may unite in an action to enjoin a breach of the covenant by other grantees. ${ }^{123}$ An action at law for damages for the breach of a restrictive covenant must be brought against the wrongdoer, and may not be brought against his grantee. ${ }^{124}$

We will now review the various violations of restrictions contained in covenants. The most common violation is the extension of the foundations of buildings, especially homes, beyond the restricted lines. When a general intention is shown by the owners of land to observe and keep a covenant of this nature alive, equity will enforce the restriction. ${ }^{125}$ Sometimes the invasion has been very slight, and unintentional; ${ }^{126}$ in most cases, however, the invasion has been clearly intended. ${ }^{127}$ In both cases

${ }^{\text {Iro }}$ Smith v. Spencer, 8I N. J. Eq. 389, 87 Ati. 158 (I9I3) ; Winslow v. Newcomb, 87 N. J. Eq. 480, 100 Atl. $6 \mathrm{r} 3$ (1917); O'Connell v. Holton, 9r N. J. Eq. 4. I07 Atl. 37 (19r9).

${ }^{120}$ Sumner v. Seaton, 47 N. J. Eq. 103, 19 Atl. 884 (1890) (reviewing many cases); Bridgewater v. Ocean City Ass'n, 85 N. J. Eq. 379, 96 Atl. 905, aff'd, 88 N. J. Eq. 35I, 102 Atl. 1052 (I9I7) ; Trout v. Lucas, supra note 53.

Zelman v. Kaufheer, 76 N. J. 52, 73 Atl. 1048 (1909); Meaney v. Stork, 80 N. J. Eq. 60, 83 Atl. 492 (I9I2) ; Leaver v. Gorman, supra note 53.

222 Trout v. Lucas, supra note 54

123 Henderson v. Champion, supra note 86; cf. Marselis v. Morris Canal Co., I N. J. Eq. 3I (I830).

12s Zelman v. Kaufheer, supra note I2I.

123 Heyniger v. Levinsohn, supra note 117.

${ }^{120}$ Wahl v. Stoy, supra note III.

127 Winfield v. Henning, supra note 30 ; Ross v. Duffy, 92 N. J. Eq. 318, 112 Atl. 485 (I921) ; Brigham v. Mulock Co., supra note I8; Loudenslager v. Pacific Imp. Co., 93 N. J. Eq. 218, II5 Atl. 752 (I92I); Kumble v. Jaffee, supra note I00; Clough v. Mesnick, 96 N. J. Eq. 482, I26 Atl. 740 (I924); Bowen v. Smith, supra note 49. 
injunctions have issued. The erection of bay windows, ${ }^{128}$ porches, ${ }^{129}$ overhanging eaves, ${ }^{130}$ and other similar extensions, has not escaped condemnation simply because they were minor additions. ${ }^{131}$ The violation in intent has just as clearly appeared in them as in more conspicuous additions. If a covenant prescribes that a house shall be built a specified distance from the street, equity will charge the conscience of the grantee with the agreement, although it neither creates an easement nor runs with the land. ${ }^{132}$ If a grantee claims that his deliberate disregard of a building restriction does not damage the grantor, he must clearly prove it. ${ }^{133}$

A common restriction is the limitation to a single residence on a lot, ${ }^{134}$ although sometimes a garage is included. ${ }^{135}$ This is violated by erecting a double house; ${ }^{138}$ or a flat-roof house adapted for the separate residence of several families; ${ }^{137}$ or the use of a private dwelling house or part of a house for a boarding house, hotel, club, ${ }^{13 s}$ or store. ${ }^{139}$ The violation is made still

${ }^{229}$ Supplee v. Cohen, 80 N. J. Eq. 83, 83 At1. 373 (I9I2) ; Strauss v. Laudenslager, 96 N. J. Eq. 678, 127 Atl. 22 (I924); Wahl v. Stoy, supra note II I.

${ }^{109}$ Ocean City Land Co. v. Weber, supra note 93 ; Buck v. Adams, 45 N. J. Eq. 552, 17 Atl. 961 (1889); Newbery v. Barkalow, supra note i8; $c f$. Marsh v. Marsh, 90 N. J. Eq. 244, 106 Atl. 81o, rev'g, 89 N. J. Eq. IIo, 104 Atl. 373 (I9I8).

${ }^{120}$ Meaney v. Stork, supra note 80 ; Supplee v. Cohen, supra note I28.

201 Righter v. Winters, 68 N. J. Eq. 252, 59 At1. 770 (1904). But cf. Meaney v. Stork, supra note 80 . See Note (I928) 55 A. L. R. 332.

132 Kirkpatrick v. Peshine, supra note 49.

${ }^{133}$ Lignot v. Jaekle, supra note 117.

${ }^{134}$ Rothholz v. Stern, 97 N. J. Eq. 189, 127 Atl. 97 (1924). As to what constitutes a private residence, see Hutchinson v. Ulrich, I45 Ill. 336, 34I, 34 N. E. 556, 557 (1893); Gillis v. Bailey, 21 N. H. 149, 155 (1850).

${ }^{135}$ Trainer v. Calef, supra. note 78 ; Kumble v. Jaffee, supra note 100.

${ }^{135}$ Koch v. Gorruflo, 77 N. J. Eq. I72, 75 Atl. 767 (IgI0) ; Shoyer v. Mermelstein, 93 N. J. Eq. 57, II4 Atl. 788 (Ig21) ; Brigham v. Mulock Co., supra note I8; cf. Underwood v. Herman \& Co., supra note 81.

${ }^{157}$ Skillman v. Smatheurst, 57 N. J. Eq. I, 40 Atl. 855 (1898).

${ }^{238}$ Bridgewater v. Ocean City R. R., supra note 63 ; Lignot v. Jaekle, supra note II7; Trainor v. LeBeck, 99 N. J. Eq. 673, 134 Atl. 355 (I926), rev'd, I39 Atl. 16 (1927); Schreiber v. Drosnes, 100 N. J. Eq. 591, 135 Atl. 920, I36 At1. $515(1926)$.

A covenant in a lease that the premises shall be used only for a saloon is not violated by not using them at all. McCormick v. Stephany, 57 N. J. Eq. 257, 41 Atl. 840 (1898).

${ }^{130}$ Cornish v. Wiessman, 56 N. J. Eq. 61o, 35 Atl. 408 (I898); Dettsloff v. Hockstetter, 96 N. J. Eq. 39I, I24 At1. 770 (I924). 
greater by erecting more than one house on a single lot; ${ }^{140}$ but a covenant providing that the grantee shall not erect any building known as a tenement or community house is not violated by erecting a two-family house, each family occupying a single floor. ${ }^{141}$ In Jones $v$. Mulligan, ${ }^{142}$ it was held that a restriction, that no building "except for cottage residence purposes" should be erected, did not prohibit the erection of a two-family house, as a cottage was a dwelling house and was not limited to a structure for the use of only one family.

The courts are unable to agree on a definition of a private residence, within the usual restriction of covenantors that only a single private residential house shall be erected on a lot. In Koch $v$. Gorrufio, ${ }^{143}$ the court held that a two-family house is not a private residence, but a collection of apartments, saying that if a covenant against anything but a private residence did not prohibit two families, a family might be put in each room and the claim still be made that the building was occupied as a private residence. This, however, represents but one view, for although the cases are rapidly multiplying the decisions in the various jurisdictions show no tendency toward harmony. ${ }^{144}$

A covenant which excludes factories is violated by erecting a light station; ${ }^{145}$ but a restrictive covenant against a livery or sales stable does not include a public garage. ${ }^{145}$ Nor is the garage a nuisance per se. ${ }^{147}$ It may, however, become one by the mode of using it. ${ }^{148}$ Moreover, a restriction prohibiting the erection of a stable within a specified distance from a street does not apply to a garage. ${ }^{149}$

${ }^{110}$ Holman v. Parker, supra note 80.

${ }^{24}$ Miller v. Cavanaugh, 94 N. J. Eq. 619, 121 Atl. 339 (ig23).

${ }^{142}$ I2I Atl. 608 (N. J. Eq. I923).

14s Supra note 136 .

14 See Note (1922) I8 A. L. R. 45I; Note (1928) 57 A. L. R. 244.

${ }^{145}$ Scrymser v. Seabright Electric Co., 74 N. J. Eq. 587, 70 Atl. 977 (I908).

${ }^{336}$ Bourgeois v. Miller, 89 N. J. Eq. 285, 104 Atl. 383 (1918).

${ }^{117}$ Diocese of Trenton v. Toman, 74 N. J. Eq. 702, 70 Atl. 606 (1908).

${ }^{148}$ O'Hara v. Nelson, 7I N. J. Eq. 161, 63 Atl. 836 (1906). As to what constitutes a nuisance, see Note (Ig27) 50 A. L. R. 107 .

${ }^{310}$ Riverbank Imp. Co. v. Bancroft, 209 Mass. 217,95 N. E. 216, 34 L. R. A. (N. s.) 730 (I9II) ; Hilsinger v. Schwartz, 99 N. J. Eq. 288, 133 Atl. 184 (1926). 
Elsewhere it has been held that a public garage is not a nuisance per se like a glue factory. A lawful business is never a nuisance so long as it is carried on reasonably and with due regard to the health and peace of others. ${ }^{150}$ Moreover, there is a distinction between a public nuisance, which is common to all the members of the public, and a private nuisance, which affects only one, or a small number. ${ }^{151}$

Two other kinds of restrictions have come before the courts for construction and enforcement. One of them relates to the sale of liquors. Violators have been persistent in disregarding a covenant of this nature, even when it has been clearly expressed. ${ }^{152}$ The restriction in one of the cases applied to a hotel. The defense was that a house dispensing drinks to a patron seated at a table, to which the public had no access, could not be regarded as a public drinking house. On this view Vice-Chancellor Leaming thus commented:

"The distinctive feature urged is that the drinker must sit and drink at a table and is not permitted to enter the room from which the drinks are served. Whether the public will drink less when required to sit in a room removed from the inspiring glitter of a bar does not appear; yet that seems to me to be the only element that can be regarded as a substantial distinguishing feature of the two situations." 153

The absence of bar glitter at the place of consumption was regarded as not enough to take the hotel out of the category of a public drinking house.

Another common covenant is that the grantor will not obstruct the view of the grantee over the remaining lands of the grantor. This is often important and valuable to the grantee. A grantor in selling land for a particular purpose cannot derogate from his grant by so using his other land as to impair or interfere with that purpose. ${ }^{154}$ The construction of a pavilion by the

\footnotetext{
${ }^{150}$ Rhodes v. Dunbar, 57 Pa. 274 (1868).

202 Phillips v. Donaldson, 269 Pa. 244, Ir2 Atl. 236 (Ig20).

${ }^{150}$ Woodbine Land \& Imp. Co. v. Riener, 72 N. J. Eq. 787, 65 Atl. I004

${ }_{100}$ Griscom v. Barcelonne, 90 N. J. Eq. 369, 372, 107 Atl. 587, 588 (1919).

$2 s$ Buck v. Adams, supra note I32.
} (1907). 
grantor on his land may clearly be a violation of his covenant. ${ }^{155}$ The rule has been thus stated in a broader way: When a grantor restricts the enjoyment of a portion of the land conveyed for the benefit of the portion retained, the restriction, if reasonable and consonant with public policy, may be enforced in equity against the grantee at the instance of the grantor. ${ }^{156}$ Moreover, this restriction is not rendered ineffective by the action of some violators. Thus, over one hundred violations of a restriction, for the preservation of a view to lot owners, has been held not to defeat the right of one of the owners to enforce the restriction against another who attempted to build a structure that would interfere with the lot owner's free and unobstructed vision. ${ }^{157}$

${ }^{150}$ Ibid.

${ }^{250}$ Hayes v. Waverly \& P. R. R., supra note 49 ; Goater v. Ely, supra note 80; Cornish v. Wiessman, supra note 144; Roberts v. Scull, 58 N. J. Eq. 396, 43 Atl. 583 ( 1899 ).

${ }^{167}$ Pearson v. Stafford, 88 N. J. Eq. 385, I02 At1. 836 (I9I8). 